\title{
10. FLUID MIXING AND ANHYDRITE PRECIPITATION WITHIN THE TAG MOUND ${ }^{1}$
}

\author{
Rachel A. Mills, ${ }^{2}$ Damon A.H. Teagle, ${ }^{3}$ and Margaret K. Tivey ${ }^{4}$
}

\begin{abstract}
Reworking of sulfide material and zone-refining during lower temperature circulation within sulfide bodies has been identified as an important process in mound accretion at mid-ocean ridge spreading centers. One site, the Trans-Atlantic Geotraverse (TAG), at $26^{\circ} \mathrm{N}$ on the Mid-Atlantic Ridge has been studied in detail by submersible and by drilling. The importance of seawater entrainment into, and fluid circulation within, the mound has been recognized as a major control on the TAG mound structure and composition. Because anhydrite composition records the seawater-hydrothermal fluid mixing process, the nature and consequences of seawater entrainment can be monitored through analysis of anhydrite recovered from the Ocean Drilling Program (ODP) sampling. $\mathrm{Sr}, \mathrm{Ca}, \mathrm{Mg}$, and the $\mathrm{Sr}$-isotopic composition of selected anhydrite samples are used here as geochemical tracers of fluid mixing and evolution during mound circulation. $\mathrm{Sr}$ and $\mathrm{Mg}$ partitioning into anhydrite is largely controlled by crystallographic controls imposed by lattice strain, though high partition coefficients are observed in surface anhydrite sample, which are inferred to be caused by the presence of a fine-grained Mg-bearing talc phase. Comparison of existing white smoker fluid data to black smoker fluid data suggests that the Sr partition coefficient for anhydrite precipitation within the TAG mound is $\leq 1$, which results in fluid evolution to high $\mathrm{Sr} / \mathrm{Ca}$ values with ongoing circulation and precipitation. Temperature variations through the mound have little effect on $\mathrm{D}_{\mathrm{Sr}}$ values, and fluid evolution arising from ongoing seawater entrainment and anhydrite precipitation is the dominant control on solid phase geochemistry. These results give new insights into subsurface fluid circulation by evaluating seawater entrainment into the mound and fluid evolution during circulation. Extensive seawater entrainment into the mound, coupled with conductive heating of the mixture, must be occurring to explain the distribution and geochemistry of TAG anhydrite.
\end{abstract}

\section{INTRODUCTION}

In 1994, the ODP drilled through the active TAG mound to determine for the first time the internal structure of an active ore deposit (Humphris et al., 1995). Although anhydrite precipitation had been predicted from fluid studies (Edmond et al., 1995; Tivey et al., 1995; Mills and Elderfield, 1995), the occurrence and location of large amounts of anhydrite within the mound have strongly influenced our understanding of the formation of sulfide structures at the seafloor (Humphris et al., 1995). Other striking results include the highly brecciated nature of the sulfide body and the occurrence of altered basalt fragments at stratigraphically shallow regions of the mound, of which both require that the entire system be highly dynamic and the mineralization episodic in nature. At TAG, the sulfide mineralization is largely above the seafloor, though a stockwork of $\sim 1.2$ million $t$ is inferred from TAG drilling results (Humphris et al., 1995). Fluids derived from the reaction zone, inferred to be at several kilometers depth (Campbell et al., 1988), exit from the apex of the mound complex. Entrainment of seawater into the mound structure is evident from submersible and drilling observations of large amounts of massive anhydrite (Thompson et al., 1988; Humphris et al., 1995; Mills and Elderfield, 1995; Tivey et al., 1995), from the fluid chemistry of white smoker and diffuse flow areas (Edmond et al., 1995; Mills and Elderfield, 1995; Tivey et al., 1995), and modeling of fluid flow (Dickson et al., 1995).

The complex interplay between entrained seawater and high-temperature fluids is evident from the range in venting styles at TAG. Diffuse flow of warm fluids that are derived from mixing of high-

${ }^{1}$ Herzig, P.M., Humphris, S.E., Miller, D.J., and Zierenberg, R.A. (Eds.), 1998 Proc. ODP, Sci. Results, 158: College Station, TX (Ocean Drilling Program).

${ }^{2}$ Department of Oceanography, Southampton Oceanography Centre, Southampton,

SO14 3ZH, United Kingdom.ram1@soc.soton.ac.uk

${ }^{3}$ Department of Geological Sciences, University of Michigan, Ann Arbor, MI 481091069, U.S.A.

${ }^{4}$ Department of Marine Chemistry and Geochemistry, Woods Hole Oceanographic Institute, Woods Hole, MA 02543, U.S.A temperature fluids with seawater is ubiquitous over the mound surface (Mills et al., 1996). Measurements of diffuse flow suggest that the chemical and mass transfer associated with such activity could be several times greater than that associated with high-temperature venting (Schultz et al., 1996), yet the chemical fluxes associated with diffuse flow are poorly known.

Anhydrite is a unique mineral within hydrothermal systems because of its retrograde solubility; the solubility of anhydrite decreases with increasing temperatures. The occurrence and composition of anhydrite within hydrothermal systems, therefore, can be used to trace the mixing of hydrothermal fluids with seawater during high-temperature venting. Precipitation and dissolution of anhydrite through time has the potential to extensively modify the structure of the mound and the composition of the solid phase and lower temperature hydrothermal fluids, and this is the subject of the present study. Such behavior is not only important within modern seafloor deposits, but has implications for on-land analogues such as Cyprus-type ore bodies (e.g., Constantinou and Govett, 1973).

\section{TAG HYDROTHERMAL MOUND}

The TAG mound is large, mature, and exhibits a complex lowtemperature circulation that involves advection of high-temperature fluids in areas of high permeability and entrainment of seawater into the mound structure. The mound is dominated by pyrite and, locally, there is evidence for zone-refining of $\mathrm{Zn}$ and $\mathrm{Cu}$ deposits (Edmond et al., 1995; Tivey et al., 1995; Humphris, Herzig, Miller, et al., 1996). Thermodynamic considerations of fluid-seawater mixing predict precipitation of anhydrite within zones of high-temperature mixing with seawater (e.g., chimney walls), though widespread precipitation of anhydrite can be explained by conductive heating of entrained seawater (Janecky and Seyfried, 1984; Janecky and Shanks, 1988; Tivey, 1995).

Anhydrite occurrence at TAG is widespread, with massive anhydrite pyrite breccias outcropping over much of the central mound complex and small, bulbous, anhydrite-dominated chimneys venting 
black smoker fluids over much of the northeast quadrant of the mound (Thompson et al., 1988; BRAVEX, 1995; Tivey et al., 1995). Drilling of the TAG mound has allowed estimation of the subsurface structure and composition (Fig. 1; Humphris et al., 1995) and quantification of the amounts of anhydrite present $\left(\sim 3 \times 10^{8} \mathrm{~kg}\right.$; Humphris et al., 1995). Anhydrite was recovered from 3 of the 5 areas drilled (TAG-1, 2, and 5; Fig. 1) throughout the range of depths drilled (up to 125 meters below seafloor (mbsf)). In all three areas, the downcore trends in anhydrite occurrence and style of mineralization are similar and an anhydrite-rich zone overlies a more siliceous zone of altered wallrock and stockwork (Fig. 1). Anhydrite occurs as veins (up to 45 $\mathrm{cm}$ thick) throughout the upper TAG-1 area, drilled $\sim 20 \mathrm{~m}$ to the southeast of the black smoker complex, and is best developed in the pyrite-anhydrite and pyrite-silica breccias (15-50 mbsf). Anhydrite abundance decreases below $\sim 33 \mathrm{mbsf}$ and occurs at depth as vugs and coatings on broken surfaces of pyrite-silica, siliceous wallrock, and chloritized basalt breccias. The TAG-2 area is in the vicinity of the "Kremlin" area of the mound ( $50 \mathrm{~m}$ southeast of the black smoker complex), where white smoker fluids had been observed to vent in 1990 and 1993 (Edmond et al., 1995). Anhydrite is less abundant in

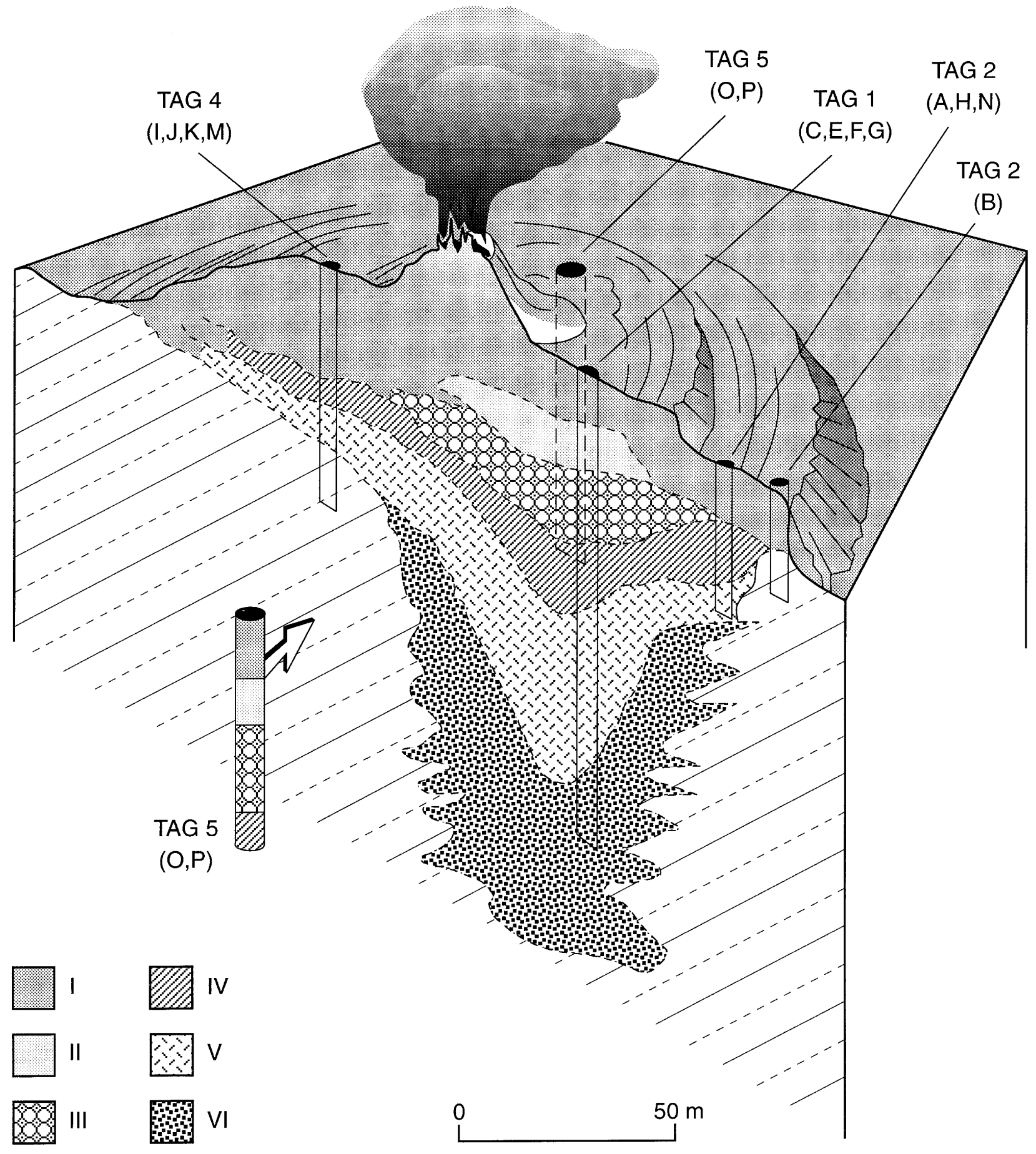

Figure 1. Lithology of the TAG active mound showing the distribution of black smoker venting, a simplified internal structure, and the drilling areas TAG-1-5. Six lithologic units have been identified and are (I) massive pyrite breccia, (II) pyrite-anhydrite breccia, (III) pyrite-silica-anhydrite breccia, (IV) pyrite-silica breccia, (V) silicified wallrock breccia, (VI) chloritized basalt breccia. Units I, II, and III compose the pyrite-dominated mound unit, and IV, V, and VI compose the stockwork. Adapted from Humphris et al. (1995). 
the TAG-2 area than at TAG-1, but a similar downcore distribution is evident that ranges from veins through to minor vug occurrences. The TAG-5 area is $\sim 20-40 \mathrm{~m}$ north of the black smoker complex, and again anhydrite veins are common in the upper mound and grade through to matrix and vug occurrences at depth.

Petrological and modeling studies of the mineralogy of surface anhydrite samples suggest extensive seawater entrainment into the mound and precipitation of anhydrite and sulfide assemblages from the mixed fluids (Tivey et al., 1995). Mound growth is inferred to occur partly via subsurface anhydrite precipitation in the upper 30-40 $\mathrm{m}$ of the deposit. Predrilling and postdrilling submersible surveys of the mound, in particular the Kremlin area, suggest that venting styles exhibit long-term variation caused by changes in fluid-circulation pathways, and black smoker fluids are now venting from the Kremlin area (BRAVEX, 1995; Schultz et al., 1996). Such observations suggest that the subsurface fluid pathways are constantly modified as mineralization and dissolution occur and larger-scale structural controls on the subsurface flow modify the circulation.

Sulfur-isotope analyses of hydrothermal sulfate minerals from various sites suggest that $\mathrm{SO}_{4}{ }^{2-}$ is solely derived from seawater and there is no oxidation of reduced sulfur occurring during mixing with seawater and precipitation (Haymon and Kastner, 1981). There is potential for S-isotopic exchange at both high and low temperature following deposition of sulfate minerals and reduction of seawater sulfate, in the low-pH regime within the mound, which will affect the $\delta^{34} \mathrm{~S}$ composition; however, the $\delta^{34} \mathrm{~S}$ compositions of TAG anhydrite samples are slightly heavier than that of seawater (Chiba et al., Chap. 6 , this volume). Ca is a major element in both hydrothermal fluids and seawater, and thus, as hydrothermal fluids mix with seawater, the proportion of $\mathrm{Ca}$ contribution from each end-member will vary.

The different and well-characterized strontium-isotopic compositions of hydrothermal fluids and seawater, and the similar strontium concentrations of these reservoirs $(\sim 90 \mu \mathrm{M})$, make Sr an ideal tracer of seawater-fluid interactions during mound circulation. TAG vent fluids have an end-member ${ }^{87} \mathrm{Sr} /{ }^{86} \mathrm{Sr}$ composition of 0.70319 (Elderfield et al., 1993), and entrainment and mixing of seawater within the TAG mound results in conservative mixing of high-temperature, relatively non-radiogenic $\mathrm{Sr}$ with radiogenic seawater $\mathrm{Sr}$ (James and Elderfield, 1996; Mills et al., 1996). Because there is no fractionation of $\mathrm{Sr}$ isotopes during mineralization, the $\mathrm{Sr}$-isotopic composition of any fluid or mineral will record the extent of hydrothermal fluid-seawater mixing within the mound. The analysis of anhydrite for ${ }^{87} \mathrm{Sr} /$ ${ }^{86} \mathrm{Sr}$ and $\mathrm{Sr}, \mathrm{Ca}$, and $\mathrm{Mg}$ concentrations can yield information on the coexisting fluid compositions and the evolving conditions of interaction. These analyses, coupled with fluid inclusion (Tivey et al., Chap. 14 , this volume), rare-earth element (Humphris et al., Chap. 19, this volume), and a combination of $\mathrm{Sr}$ and oxygen isotope analyses (Alt and Teagle, Chap. 21, this volume; Teagle et al., Chap. 22, this volume; Teagle et al., Chap. 11, this volume), allow reconstruction of fluid evolution history within the TAG mound.

\section{METHODOLOGY}

A range of anhydrite samples from the drill core were subsampled on board, and one additional submersible-collected sample (ALV 1677-2) from the TAG-1 area was analyzed (Table 1). Approximately $20 \mathrm{mg}$ of hand-picked anhydrite samples were crushed in agate and $1 \mathrm{~mL}$ of quartz distilled (QD) water. Samples were diluted to $2-3 \mathrm{~mL}$ with QD $\mathrm{H}_{2} \mathrm{O}$, a drop of $6 \mathrm{~N} \mathrm{HCl}$ was added and the mixture was left on a hot plate in a capped tetrafluoroethylene Savillex beaker until dissolution was complete. Strontium, $\mathrm{Mg}$, and $\mathrm{Ca}$ determinations on dissolved anhydrite solutions were conducted by inductively coupled plasma atomic emission spectrometry (ICPAES) and are shown in Table 2. The reproducibility of these analyses is better than $1 \%$.

$\mathrm{Sr}$ separations for isotopic determinations were carried out in Cambridge by cation exchange, loaded in acidified QD water and eluted with $1.75 \mathrm{M} \mathrm{HCl}$. Procedural blanks were $<200 \mathrm{pg}$ for Sr. At the University of Michigan, samples were evaporated to incipient dryness and then taken up in $0.2 \mathrm{~mL}$ of $3 \mathrm{M} \mathrm{HNO}_{3}$ before loading on fresh, cleaned, $\mathrm{Sr}-\mathrm{Spec}$ (Eichrom Corporation) columns with a resin bed volume of $\approx 0.07 \mathrm{~mL}$. Major elements were eluted with $1 \mathrm{~mL}$ of $3 \mathrm{M} \mathrm{HNO}_{3}$ before collecting $\mathrm{Sr}$ in $1 \mathrm{~mL}$ of $\mathrm{H}_{2} \mathrm{O}$. Full analytical procedural blanks at the University of Michigan were $<50 \mathrm{pg}$ for $\mathrm{Sr}$.

Strontium-isotopic compositions were determined by thermal ionization mass spectrometry (TIMS) at the Southampton Oceanography Centre (SOC) and in the Radiogenic Isotope Geochemistry Laboratory (RIGL) at the University of Michigan as part of a larger study of the Sr-isotope systematics of the TAG mound (Alt and Teagle, Chap. 21, this volume; Teagle et al., Chap. 22, this volume; Teagle et al., Chap. 11, this volume). Strontium-isotopic compositions $\left({ }^{87} \mathrm{Sr} /{ }^{86} \mathrm{Sr}\right)$ were determined by loading on single Ta filaments with $\mathrm{TaF}_{5}$ in phosphoric acid or single Re filaments with a $\mathrm{TaCl}_{5}$ solution and 5\% phosphoric acid, respectively. SOC Sr-isotopic measurements were analyzed using a Fisons Sector 54 multicollector by multidynamic peak switching. External precision for these measurements is better than 0.000025 ( $2 \sigma$ standard error [SE]). Samples were analyzed at the University of Michigan on a V.G. Sector-II multiple collector mass spectrometer, using a $2.0 \pm 0.2 \times 10^{-11} \mathrm{~A}$ ion beam with at least 200 ratios collected in a multidynamic mode and normalized to ${ }^{86} \mathrm{Sr} /{ }^{88} \mathrm{Sr}=0.1194$. For the period of the analysis (January 1996) NIST SRM 987 gave ${ }^{87} \mathrm{Sr} /{ }^{86} \mathrm{Sr}=0.710214 \pm 0.000018(2 \sigma, \mathrm{n}=$ 20) and University of Michigan data have been normalized to a ${ }^{87} \mathrm{Sr} /$ ${ }^{86} \mathrm{Sr}$ value of 0.710237 .

\section{RESULTS AND DISCUSSION}

The $\mathrm{Sr}, \mathrm{Mg}, \mathrm{Ca}$, and $\mathrm{Sr}$ isotopic geochemistry of anhydrite samples is shown in Table 2 and data are expressed as molar element/Ca values. The downcore variation of the $\mathrm{Sr}$-isotopic composition is shown in Figure 2 and is compared with seawater and hydrothermal fluid compositions and a generalized lithology of the TAG mound. Units I, II, and III to $45 \mathrm{mbsf}$ represent the exhalative, sulfide deposit, and Units IV, V and VI, to $120 \mathrm{mbsf}$, are from the underlying stockwork. The ${ }^{87} \mathrm{Sr} /{ }^{86} \mathrm{Sr}$ value of TAG anhydrite varies from 0.706347 to 0.709128 , suggesting a seawater-dominated circulation throughout most of the active mound, to $120 \mathrm{~m}$ depth. Values close to seawater are observed within the stockwork at $58 \mathrm{~m}$ in the TAG-5 area and 120 $\mathrm{m}$ in the TAG-1 area, suggesting that these samples are from areas of seawater recharge and entrainment that is restricted from mixing with rising hydrothermal fluids. Samples from coherent units within the sulfide-hosted anhydrite veins exhibit large variations in ${ }^{87} \mathrm{Sr} /{ }^{86} \mathrm{Sr}$ over small spatial scales, demonstrating heterogeneity in fluid flow parameters on the scale of vein formation (See also Fig. 3; Teagle et al., Chap. 11, this volume).

$\mathrm{The} \mathrm{Sr} / \mathrm{Ca}$ and $\mathrm{Mg} / \mathrm{Ca}$ values range from 4.4 to $13 \mathrm{mmol} / \mathrm{mol}$ and from 0.7 to $11 \mathrm{mmol} / \mathrm{mol}$, respectively, and downcore variations are shown in Figures 3A and 3B. Sr/Ca values decrease downcore, surface samples exhibit values significantly greater than any fluid composition (Fig. 3A; R.A. Mills, unpubl. data), and samples at depth exhibit lower $\mathrm{Sr} / \mathrm{Ca}$ values. $\mathrm{Mg} / \mathrm{Ca}$ values are high in the two surface samples and consistently low throughout the rest of the mound. High $\mathrm{Mg} / \mathrm{Ca}$ values have been observed in most surface anhydrite samples (R.A. Mills, unpubl. data). $\mathrm{Mg}$ is inferred to be quantitatively removed from seawater during hydrothermal recharge, and $\mathrm{Mg}$ in anhydrite is derived solely from seawater. However, there is no significant correlation between ${ }^{87} \mathrm{Sr} /{ }^{86} \mathrm{Sr}$ and either $\mathrm{Sr} / \mathrm{Ca}$ or $\mathrm{Mg} / \mathrm{Ca}$ value.

The relative proportions of seawater and hydrothermal component in a fluid can be calculated from

$$
\begin{aligned}
& \% \text { hydrothermal component }=100 \times \\
& {\left[{ }^{87} \mathrm{Sr} /{ }^{86} \mathrm{Sr}_{\mathrm{SW}} \times(\mathrm{Sr})_{\mathrm{SW}}\right]-\left[{ }^{87} \mathrm{Sr} /{ }^{86} \mathrm{Sr}_{\mathrm{M}} \times(\mathrm{Sr})_{\mathrm{SW}}\right]} \\
& \overline{\left[{ }^{87} \mathrm{Sr} /{ }^{86} \mathrm{Sr}_{\mathrm{SW}} \times(\mathrm{Sr})_{\mathrm{SW}}\right]-\left[{ }^{87} \mathrm{Sr}^{8{ }^{86}} \mathrm{Sr}_{\mathrm{HT}} \times(\mathrm{Sr})_{\mathrm{HT}}\right]+\left\{{ }^{87} \mathrm{Sr}^{86} \mathrm{Sr}_{\mathrm{M}} \times\left[(\mathrm{Sr})_{\mathrm{HT}}-(\mathrm{Sr})_{\mathrm{SW}}\right]\right\}}
\end{aligned}
$$


Table 1. Anhydrite sample descriptions.

\begin{tabular}{lrl}
\hline \multicolumn{1}{c}{ Sample } & $\begin{array}{c}\text { Depth } \\
\text { (mbsf) }\end{array}$ & \\
\hline TAG-1 & & \multicolumn{1}{c}{ Description } \\
*ALV 1677-2 & 0.0 & Massive anhydrite \\
*158-957C-11N-1 (Piece 3K) & 32.01 & $\begin{array}{l}\text { Banded vein with some hematite } \\
\text { 158-957C-11N-3 (Piece 5A) }\end{array}$ \\
158-957C-11N-3 (Piece 6) & 33.99 & Vein and selvage in pyrite-silica-anhydrite breccia \\
*158-957C-11N-3 (Piece 10B) & 34.82 & Anhydrite vein with pyrite \\
*158-957C-11N-3 (Piece 10B) & 34.82 & Vein in pyrite silica breccia, with cp breccia, with py \\
158-957E-11R-1 (Piece 2) & 87.16 & Outer surface of massive granular pyrite sample \\
158-957E-15R-1 (Piece 2) & 106.54 & Outer surface of chloritized basalt breccia clast \\
*158-957E-17R-1 (Piece 2) & 116.18 & Broken surface of chloritized basalt breccia \\
*158-957E-18R-1 (Piece 4) & 120.89 & Vein in chloritized basalt breccia, with py \\
TAG-2 & & \\
*158-957H-1N-1 (Piece 9) & 9.08 & Vein and matrix of cp-rich porous massive pyrite \\
158-957H-5N-1 (Piece 5B) & 27.20 & 1-cm-thick vein in nodular pyrite silica breccia \\
158-957H-5N-2 (Piece 1D) & 27.86 & Fine-grained vein in silicified wallrock breccia \\
158-957H -5N-2 (Pieces 1D + 1B + 1C) & 27.86 & Fine-grained veins and vugs in silicified wallrock breccia \\
*158-957H-5N-2 (Pieces 3C-3V) & 28.39 & Large vug around silica clast in silicified wallrock breccia \\
158-957H-6N-1 (Piece 5) & 31.46 & Vug in nodular pyrite-silica breccia \\
*158-957H-9X-1 (Piece 4) & 44.85 & Broken surface of massive pyrite breccia with cp and py \\
TAG-5 & & \\
158-957O-2R-1 (Piece 4) & 8.03 & Veins and outer surface from nodular py breccia \\
158-957P-1R-1 (Piece 1) & 0.0 & Veins and vugs from massive pyrite-anhydrite breccia \\
158-957P-11R-1 (Piece 7) & 50.41 & Broken outer surface of pyrite silica breccia \\
*158-957P-12R-4 (Piece 11) & 57.99 & Broken outer surface of massive granular pyrite \\
\hline & &
\end{tabular}

Note: * samples studied for fluid inclusions (Tivey et al., Chap. 14, this volume); py = pyrite; $\mathrm{cp}=$ chalcopyrite.

where subscripts SW, HT, and M refer to seawater, hydrothermal fluid, and measured values respectively (Table 2) and [Sr] refers to concentrations in solution. TAG anhydrite samples demonstrate a range of hydrothermal fluid-seawater mixtures from approximately equal proportions of each, to seawater-dominated fluids (43:57 to $0.5: 99.5)$. These data can then be used to predict the $\mathrm{Sr}, \mathrm{Ca}$, and $\mathrm{Mg}$ content of the parent fluid that precipitated the anhydrite within the mound, assuming that mixing occurs prior to precipitation. Predicted $\mathrm{Sr} / \mathrm{Ca}$ and $\mathrm{Mg} / \mathrm{Ca}$ values are shown in Table 2.

Cations are assumed to be present in VIII-fold coordination within the anhydrite lattice and the effective ionic radii in VIII-fold coordination are relatively well known (Shannon, 1976). The Sr/Ca values of TAG anhydrite are similar or higher than that of seawater (8.54 $\mathrm{mmol} / \mathrm{mol})$ and TAG black smoker fluid $(3.34 \mathrm{mmol} / \mathrm{mol})$ and reflects the ready substitution of $\mathrm{Sr}$ into the $\mathrm{CaSO}_{4}$ lattice due to the similarity of cationic radius $\left(\mathrm{Sr}^{2+}=1.26 \AA ; \mathrm{Ca}^{2+}=1.12 \AA\right.$; Shannon, 1976) and the charge balance. The ionic radius of $\mathrm{Mg}$ is $0.89 \AA$ (Shannon, 1976) and therefore substitution into the anhydrite lattice is limited by the mismatch in ionic radius; this is reflected in the extremely low $\mathrm{Mg} / \mathrm{Ca}$ value compared with that calculated from seawater-fluid mixing (Table 2). However, near-surface samples show enhanced $\mathrm{Mg} / \mathrm{Ca}$ values, which are inferred to be caused by the coexistence of a Mg-rich phase rather than extensive lattice substitution of $\mathrm{Mg}$ into anhydrite.

A number of laboratory investigations of the partition coefficients of trace elements into crystalline systems during unidirectional mineralization suggest that a Doerner-Hoskins model is an appropriate description of the system (Shikazono and Holland, 1983). This approach assumes that the partitioning of trace elements between solid and solution phase is controlled by a partition coefficient, $D$, where

$$
D_{\mathrm{Sr}}=\frac{(\mathrm{Sr} / \mathrm{Ca})_{\text {solid }}}{(\mathrm{Sr} / \mathrm{Ca}) \text { fluid }}
$$

In the TAG system, where fluid flow through the mound is rapid and there are large fluctuations and gradients in temperature and fluid composition, it is inferred that the partition coefficient, $D$, may be very different from the equilibrium thermodynamic constant, $K_{D}$.

Apparent partition coefficients for TAG anhydrite samples can be calculated from the measured element/Ca value and that inferred from the proportion of hydrothermal and seawater in the parental flu- id (Table 2). These apparent $D_{\mathrm{Sr}}$ and $D_{\mathrm{Mg}}$ values are shown in Table 2 and plotted downcore in Figures 4A and 4B.

Lattice substitution depends on the effective ionic radius of the substituting cation compared with the lattice-bound cation radius, the charge balance, and the degree of equilibrium achieved (Blundy and Wood, 1994). The Mg cationic radius is not suitable for extensive replacement into the anhydrite lattice; however, some substitution is evident from the $\mathrm{Mg} / \mathrm{Ca}$ values of anhydrite (Table 2). If the difference in partition coefficient is a function of lattice strain arising from cationic radius mismatch, then the $D_{\mathrm{Mg}}$ value should be related to the $D_{\mathrm{Sr}}$ value by (after Blundy and Wood, 1994)

$D_{\mathrm{Mg}}=D_{\mathrm{Sr}} \exp \left\{\frac{-4 \pi \hat{E} N_{A}\left[\frac{r_{\mathrm{Sr}}}{2}\left(r_{\mathrm{Mg}}-r_{\mathrm{Sr}}\right)^{2}+\frac{1}{3}\left(r_{\mathrm{Mg}}-r_{\mathrm{Sr}}\right)^{3}\right]}{R T}\right\}$

where $E$ is the Young's Modulus for anhydrite $\left(0.73 \times 10^{11} \mathrm{Nm}^{-2}\right.$; Birch, 1966), $N_{A}$ is Avogadro's number, $r_{\mathrm{Sr}}$ and $r_{\mathrm{Mg}}$ are the $\mathrm{Sr}$ and $\mathrm{Mg}$ ionic radii, $T$ is the temperature of anhydrite formation $(\sim 623 \mathrm{~K})$ and $R$ is the gas constant. Substituting values into Equation 3 suggests that $D_{\mathrm{Mg}}$ values should be $\sim 6 \times 10^{-4} D_{\mathrm{Sr}}$. Apparent $D_{\mathrm{Mg}}$ values are close to this value for all samples other than the two surface samples (Table 2), suggesting that lattice mismatch is an important factor in controlling $\mathrm{Mg}$ and $\mathrm{Sr}$ distributions between solution and anhydrite within the mound. $\mathrm{D}_{\mathrm{Mg}}$ values for surface samples are higher than that predicted for strain compensated substitution, and similar high values have been observed for submersible-collected samples (R.A. Mills, unpubl. data) suggesting that some additional $\mathrm{Mg}$ removal is occurring at the mound-seawater interface. No caminite (Mg-hydroxysulfate; MHSH) has been observed in TAG drill material; therefore, the most likely Mg-rich components are Mg-rich talc phases present in interstitial spaces between picked anhydrite grains. This material will be readily leached by the methodology used here leading to the high $\mathrm{Mg} / \mathrm{Ca}$ values observed.

\section{TEMPERATURE}

A number of attempts have been made to quantify $\mathrm{Sr}$ partitioning into anhydrite during formation. Shikazono and Holland (1983) pre- 
Table 2. Major-element geochemistry and Sr-isotope composition of anhydrite.

\begin{tabular}{|c|c|c|c|c|c|c|c|c|c|}
\hline Sample & $\begin{array}{c}\mathrm{Sr} / \mathrm{Ca} \\
(\mathrm{mmol} / \mathrm{mol})\end{array}$ & $\begin{array}{c}\mathrm{Mg} / \mathrm{Ca} \\
(\mathrm{mmol} / \mathrm{mol})\end{array}$ & ${ }^{87} \mathrm{Sr} /{ }^{86} \mathrm{Sr}$ & $\begin{array}{c}\text { Hydrothermal } \\
\text { component } \\
(\%)\end{array}$ & $\begin{array}{l}\text { Seawater } \\
\text { component } \\
(\%)\end{array}$ & $\begin{array}{c}\text { Predicted } \\
\mathrm{Sr} / \mathrm{Ca} \\
(\mathrm{mmol} / \mathrm{mol})\end{array}$ & $\begin{array}{c}\text { Predicted } \\
\mathrm{Mg} / \mathrm{Ca} \\
(\mathrm{mmol} / \mathrm{mol})\end{array}$ & $\begin{array}{c}\text { Apparent } \\
D_{\mathrm{Sr}}\end{array}$ & $\begin{array}{c}\text { Apparent } \\
D_{\mathrm{Mg}} \\
\left(\times 10^{-3}\right)\end{array}$ \\
\hline \multicolumn{10}{|l|}{ TAG-1 } \\
\hline *ALV 1677-2 & 13.7 & 11.7 & 0.707214 & 29 & 71 & 5.65 & 2.21 & 2.43 & 5.30 \\
\hline *158-957C-11N-1 (Piece 3K) & & & 0.706370 & 43 & 57 & 4.92 & 1.77 & & \\
\hline 158-957C-11N-3 (Piece 5A) & & & 0.706695 & 38 & 62 & 5.17 & 1.94 & & \\
\hline $158-957 \mathrm{C}-11 \mathrm{~N}-3$ (Piece 6$)$ & & & 0.706694 & 38 & 62 & 5.17 & 1.94 & & \\
\hline *158-957C-11N-3 (Piece 10B) & & & 0.707283 & 28 & 72 & 5.69 & 2.23 & & \\
\hline *158-957C-11N-3 (Piece 10B) & & & 0.706846 & 35 & 65 & 5.29 & 2.01 & & \\
\hline 158-957E-11R-1 (Piece 2) & 6.77 & 1.06 & 0.707870 & 19 & 81 & 6.36 & 2.52 & 1.06 & 0.420 \\
\hline 158-957E-15R-1 (Piece 2) & 6.78 & 3.37 & 0.707690 & 22 & 78 & 6.15 & 2.44 & 1.10 & 1.38 \\
\hline *158-957E-17R-1 (Piece 2) & 4.44 & 2.12 & 0.708155 & 15 & 85 & 6.73 & 2.66 & 0.660 & 0.798 \\
\hline *158-957E-18R-1 (Piece 4) & 4.50 & 0.747 & 0.709128 & 0.5 & 99.5 & 8.39 & 3.10 & 0.536 & 0.241 \\
\hline \multicolumn{10}{|l|}{ TAG-2 } \\
\hline *158-957H-1N-1 (Piece 9) & 6.24 & 1.72 & 0.707251 & 29 & 71 & 5.68 & 2.22 & 1.10 & 0.773 \\
\hline 158-957H-5N-1 (Piece 5B) & 11.3 & 2.56 & 0.707103 & 31 & 69 & 5.54 & 2.15 & 2.04 & 1.19 \\
\hline $158-957 \mathrm{H}-5 \mathrm{~N}-2$ (Piece 1D) & & & 0.707924 & 18 & 82 & 6.43 & 2.55 & & \\
\hline $158-957 \mathrm{H}-5 \mathrm{~N}-2($ Pieces $1 \mathrm{D}+1 \mathrm{~B}+1 \mathrm{C})$ & & & 0.707625 & 23 & 77 & 6.07 & 2.41 & & \\
\hline$* 158-957 \mathrm{H}-5 \mathrm{~N}-2($ Pieces $3 \mathrm{C}-3 \mathrm{~V})$ & & & 0.707249 & 29 & 71 & 5.68 & 2.22 & & \\
\hline $158-957 \mathrm{H}-6 \mathrm{~N}-1$ (Piece 5$)$ & 8.78 & 1.04 & 0.707030 & 32 & 68 & 5.47 & 2.12 & 1.60 & 0.492 \\
\hline *158-957H-9X-1 (Piece 4) & 7.74 & 2.76 & 0.706866 & 35 & 65 & 5.33 & 2.03 & 1.45 & 1.36 \\
\hline \multicolumn{10}{|l|}{ TAG-5 } \\
\hline 158-957O-2R-1 (Piece 4) & 9.18 & 3.18 & 0.707260 & 29 & 71 & 5.69 & 2.23 & 1.61 & 1.43 \\
\hline 158-957P-1R-1 (Piece 1) & 12.4 & 11.6 & 0.707383 & 27 & 73 & 5.81 & 2.29 & 2.13 & 5.07 \\
\hline 158-957P-11R-1 (Piece 7) & 9.26 & 1.62 & 0.707796 & 20 & 80 & 6.27 & 2.49 & 1.48 & 0.651 \\
\hline$* 158-957 \mathrm{P}-12 \mathrm{R}-4$ (Piece 11) & 6.72 & 1.10 & 0.708847 & 5 & 95 & 7.83 & 2.98 & 0.858 & 0.370 \\
\hline
\end{tabular}

Note: $*$ samples studied for fluid inclusions (Tivey et al., Chap. 14, this volume).

cipitated anhydrite in the laboratory and observed a relationship between anhydrite morphology and partition coefficient. The partition coefficient for rectangular anhydrite falls in the range $0.27-0.35$, whereas acicular anhydrite, which was observed to precipitate from more extremely supersaturated solutions, was observed to precipitate with a higher $D_{\mathrm{Sr}}$ of $0.52-0.55$. Other experiments have addressed the role of temperature in the value of $D_{\mathrm{Sr}}$ (Kushnir, 1982) and a general inverse trend with increasing temperature is apparent in the literature (Shikazono and Holland, 1983), which extrapolates to a $D_{\mathrm{Sr}}$ value of $<0.1$ at $350^{\circ} \mathrm{C}$. The only published estimate of $D_{\mathrm{Sr}}$ values for natural hydrothermal systems is from East Pacific Rise $21^{\circ} \mathrm{N}$ anhydrite samples, which fall in the range of 0.74-1.1 (Shikazono and Holland, 1983). These studies suggest that natural systems do not behave like simple laboratory mixing and heating experiments.

Homogenization temperatures from microthermometric analyses of fluid inclusions in TAG anhydrite suggest that mineralization occurs within a narrow range of temperatures in the TAG- 1 and TAG2 areas $\left(337^{\circ}-388^{\circ} \mathrm{C}\right.$ and $280^{\circ}-369^{\circ} \mathrm{C}$, respectively), with a larger range in the TAG-5 area $\left(187^{\circ}-337^{\circ} \mathrm{C}\right.$, Tivey et al., Chap. 14 , this volume). Temperatures inferred from fluid inclusion microthermometry increase downcore and, although there is a concurrent decrease in apparent $D_{\mathrm{Sr}}$ within the mound anhydrite with depth (Fig. 5), there is no good correlation between temperature and partition coefficient because the temperature range within the TAG mound is too small to greatly influence Sr partitioning into anhydrite. We infer that temperature plays only a minor role in controlling the apparent distribution coefficient for $\mathrm{Sr}$ in TAG anhydrite.

\section{EVIDENCE FOR FLUID EVOLUTION}

White smoker fluids collected from the Kremlin area of the TAG mound have been characterized extensively (Mitra et al., 1994; Edmond et al., 1995) and modeling of major element and REE compositions suggest that $\sim 0.3 \mathrm{~g}$ of anhydrite $/ \mathrm{kg}$ fluid precipitates within the mound prior to venting in the Kremlin area (Mills and Elderfield, 1995; Tivey et al., 1995). Sr and Ca measurements have also been made on the same fluid samples (Edmond et al., 1995) allowing estimation of the removal of $\mathrm{Sr}$ and $\mathrm{Ca}$ into anhydrite within the mound and, hence, the partition coefficient of anhydrite involved in this pro- cess. Black smoker and white smoker $\mathrm{Ca}$ and $\mathrm{Sr}$ contents are shown in Table 3. Tivey et al. (1995) have demonstrated that white smoker fluids contain $\sim 14 \%$ entrained seawater, which allows anhydrite precipitation to occur subsurface; thus, the zero correction for white smoker fluids underestimates the $\mathrm{Ca}$ removal via anhydrite precipitation. Hence, the white smoker and black smoker data are normalized to $14 \%$ seawater content here to allow direct comparison of the $\mathrm{Sr} / \mathrm{Ca}$ value of the two fluids and, therefore, allow calculation of the mean partition coefficient for anhydrite precipitation subsurface, assuming that the major control on Sr and Ca chemistry in white smoker fluids is removal via anhydrite precipitation. Anhydrite precipitation can be modeled as a Rayleigh-type distillation, assuming that the $\mathrm{Ca}$ concentration in anhydrite is large, whereas that in solution is dilute (i.e., $\left.D_{\mathrm{Ca}} \gg 1\right)$

$$
\left(\frac{\mathrm{Sr}}{\mathrm{Ca}}\right)_{f}=\left(\frac{\mathrm{Sr}}{\mathrm{Ca}}\right)_{0}(F)^{\left(D_{\mathrm{Sr}}-1\right)}
$$

where the subscripts $f$ and 0 refer to final and initial fluid compositions respectively, $F$ is the fraction of original $\mathrm{Ca}$ remaining in solution. Substituting values for black and white smoker fluids normalized to $14 \%$ seawater content (Table 3 ) gives a $D_{\mathrm{Sr}}$ value of 0.86 . If zero $\mathrm{Mg}$ values are used, the inferred $D_{\mathrm{Sr}}$ value is 0.94 . These estimates are consistent with observations from diffuse flow fluids of $D_{\mathrm{Sr}} \leq 1$ (James and Elderfield, 1996). Precipitation of anhydrite with $D_{\mathrm{Sr}}<1$ results in evolution of the fluid-seawater mixture to higher $\mathrm{Sr} / \mathrm{Ca}$ values; as precipitation continues subsurface, so the $\mathrm{Sr} / \mathrm{Ca}$ value will increase further.

Figure 4A demonstrates the downcore decrease in $D_{\mathrm{Sr}}$ with depth to values close to experimental data and the mean $D_{\mathrm{Sr}}$ inferred from white smoker fluid composition. This trend suggests that the mound is permeable to depths of $>100 \mathrm{~m}$ where seawater entrainment results in anhydrite precipitation, with $D_{\mathrm{Sr}}$ values close to experimental conditions (Shikazono and Holland, 1983). Such anhydrite is present as vugs and veins around altered basaltic clasts in the stockwork zone.

The sulfide-hosted anhydrite veins, from Units I, II, and III, exhibit high apparent $D_{\mathrm{Sr}}$ values, suggesting that these samples precipitate from evolved fluid-seawater mixtures, with higher $\mathrm{Sr} / \mathrm{Ca}$ values. As the fluids circulate within the mound and continuously entrain seawater and precipitate anhydrite, the $\mathrm{Sr} / \mathrm{Ca}$ value will evolve to higher values. The data presented here do not allow quantitative eval- 


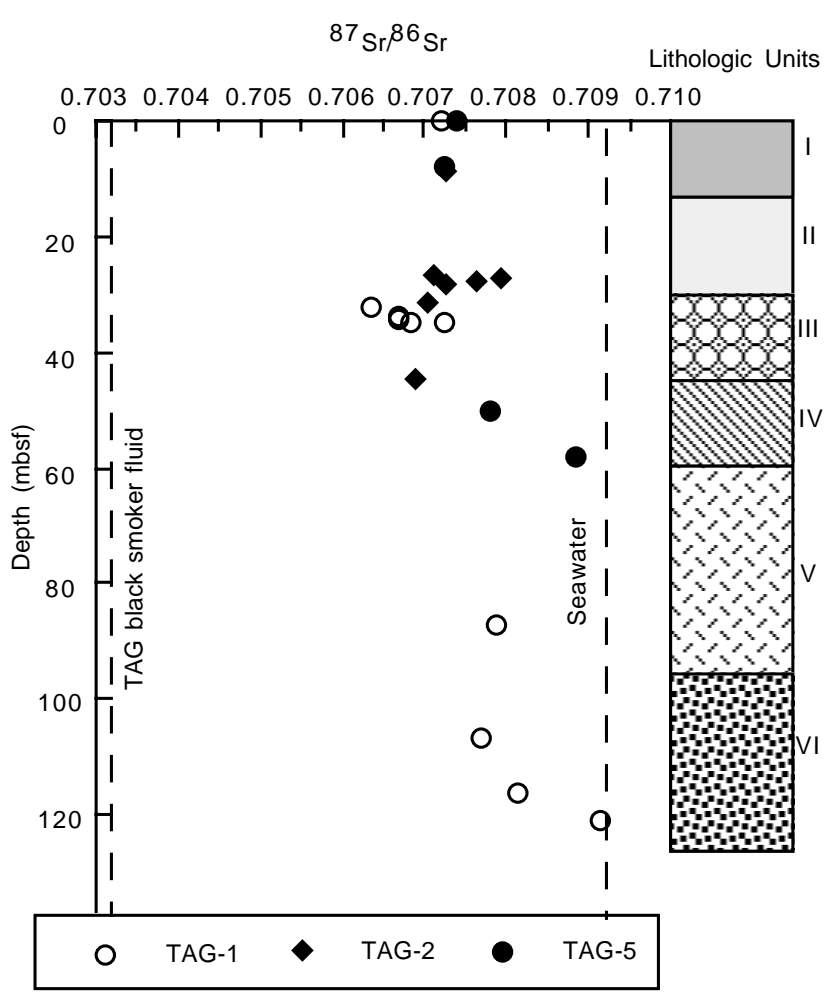

Figure 2. Downcore variation in ${ }^{87} \mathrm{Sr} /{ }^{86} \mathrm{Sr}$ within the TAG mound. TAG black smoker fluid and seawater values are shown for comparison. Lithology as in Figure 1.

uation of the extent of fluid evolution during mound circulation and this is the focus of ongoing studies.

\section{TIME SCALES FOR MOUND DEVELOPMENT}

TAG drilling estimates of anhydrite inventory for TAG are of the order of $10^{5} \mathrm{~m}^{3}\left(\sim 3 \times 10^{8} \mathrm{~kg}\right)$. This amount of anhydrite could be precipitated from $\sim 10^{12} \mathrm{~kg}$ fluid at the rates suggested by the white smoker fluid chemistry (Mills and Elderfield, 1995). Conservative estimates of fluid flow from TAG $\left(10^{10}\right.$ to $10^{11} \mathrm{~kg} /$ year; James and Elderfield, 1996) indicate that anhydrite is extremely rapidly precipitated within the mound. Assuming that $5 \%$ of the fluid flow occurs as white smoker style venting, then the entire anhydrite inventory could be precipitated in 200-2000 yr. Lower temperature diffuse flow also plays a major role in the TAG anhydrite budget (James and Elderfield, 1996).

Whereas previous studies of fluid compositions and samples from the surface of the mound indicated significant seawater entrainment into the mound (Tivey et al., 1995), they did not provide information on depths of entrainment, or on the complexities of entrainment, mixing, and precipitation. Data from anhydrite samples recovered from within the mound by drilling indicate that the internal fluid regime is complex and involves deep-seated recharge and pooling and evolution of fluids at shallow depths within the mound. A schematic representation of the fluid flow is shown in Figure 6 with arrows demonstrating the fluid-flow regime indicated from the present study.

\section{CONCLUSIONS}

The TAG mound is permeable to seawater to at least $120 \mathrm{~m}$ depth, and Sr-isotopic data indicate that anhydrite recovered from the stockwork zone is formed from conductively heated seawater with little hydrothermal fluid influence. Such anhydrite precipitation occurs close to laboratory-determined experimental conditions with $D_{\mathrm{Sr}}<1$. Substitution of $\mathrm{Sr}$ and $\mathrm{Mg}$ into the anhydrite lattice is largely controlled by suitability of cationic radius for substitution of $\mathrm{Ca}$ within the crystal lattice. The downcore variation in apparent $D_{\mathrm{Sr}}$ is not temperature controlled; instead, there is significant fluid evolution as ongoing precipitation of anhydrite and continued entrainment of seawater into the mound occurs. The upper, anhydrite-rich portion of the mound is dominated by pooled, evolved fluids that form the complex vein structures recovered during drilling.

A fluid-circulation model for the mound is proposed that is consistent with the $\mathrm{Sr}, \mathrm{Mg}$, and Ca geochemistry of anhydrite retrieved from within the TAG mound. These drilling results have important implications for models of volcanic-hosted massive sulfide ore body formation because they demonstrate the rapid nature of anhydrite precipitation, the extensive seawater penetration into the mound structure, and the complex internal fluid plumbing that is continuously modified on small spatial scales.

\section{ACKNOWLEDGMENTS}

Thanks are extended to Harry Elderfield, Bob Nesbitt, and Alex Halliday for supplying laboratory facilities, and Darryl Green and Andy Milton for carrying out some of the UK analyses. Rex Taylor was invaluable with TIMS support. The final manuscript benefited from reviews from M. Berndt, D. Butterfield, and K. Rubin. This research was supported by NERC grant GST/02/0976; BRIDGE and United Kingdom ODP contributed to participation in the Leg 158 post-cruise meeting. Teagle and Tivey were supported by postcruise research grants from JOI-USSAC.

\section{REFERENCES}

Birch, F., 1966. Compressibility: elastic constants. In Handbook of Physical Constants. Mem.-Geol. Soc. Am., 97:97-173.

Blundy, J., and Wood, B., 1994. Prediction of crystal-melt partition coefficients from elastic modulii. Nature, 372:452-454.

BRAVEX, 1995. The effects of ODP drilling on the TAG hydrothermal mound: the TAG post-drilling survey. BRIDGE Newsl., 8:7-11.

Campbell, A.C., Palmer, M.R., Klinkhammer, G.P., Bowers, T.S., Edmond, J.M., Lawrence, J.R., Casey, J.F., Thompson, G., Humphris, S., Rona, P.A., and Karson, J.A., 1988. Chemistry of hot springs on the Mid-Atlantic Ridge. Nature, 335:514-519.

Constantinou, G., and Govett, G.J.S., 1973. Geology, geochemistry, and genesis of Cyprus sulfide deposits. Econ. Geol., 68:843-858.

Dickson, P., Schultz, A., and Woods, A., 1995. Preliminary modelling of hydrothermal circulation within mid-ocean ridge sulphide structures. In Parson, L.M., Walker, C.L., and Dixon, C.L. (Eds.), Hydrothermal Vents and Processes. Geol. Soc. Spec. Publ. London, 87:145-158.

Edmond, J.M., Campbell, A.C., Palmer, M.R., German, C.R., Klinkhammer, G.P., Edmonds, H.N., Elderfield, H., Thompson, G., and Rona, P., 1995. Time series studies of vent fluids from the TAG and MARK sites (1986, 1990): Mid-Atlantic Ridge: a new solution chemistry model and a mechanism for $\mathrm{Cu} / \mathrm{Zn}$ zonation in massive sulfide ore bodies. In Parson, L.M., Walker, C.L., and Dixon, D.R. (Eds.), Hydrothermal Vents and Processes. Geol. Soc. Spec. Publ. London, 87:77-86.

Elderfield, H., Mills, R.A., and Rudnicki, M.D., 1993 Geochemical and thermal fluxes, high-temperature venting and diffuse flow from mid-ocean ridge systems: the TAG hydrothermal field, Mid-Atlantic Ridge $26^{\circ} \mathrm{N}$. Geol. Soc. Spec. Publ. London, 76:295-307.

Haymon, R.M., and Kastner, M., 1981. Hot spring deposits on the East Pacific Rise at $21^{\circ} \mathrm{N}$ : preliminary description of mineralogy and genesis. Earth Planet. Sci. Lett., 53:363-381.

Humphris, S.E., Herzig, P.M., Miller, D.J., et al., 1996. Proc. ODP, Init. Repts., 158: College Station, TX (Ocean Drilling Program).

Humphris, S.E., Herzig, P.M., Miller, D.J., Alt, J.C., Becker, K., Brown, D., Brügmann, G., Chiba, H., Fouquet, Y., Gemmell, J.B., Guerin, G., Hannington, M.D., Holm, N.G., Honnorez, J.J., Itturino, G.J., Knott, R., Ludwig, R., Nakamura, K., Petersen, S., Reysenbach, A.-L., Rona, P.A., 
Smith, S., Sturz, A.A., Tivey, M.K., and Zhao, X., 1995. The internal structure of an active sea-floor massive sulphide deposit. Nature, 377:713-716

James, R.H., and Elderfield, H., 1996. The chemistry of ore-forming fluids and mineral precipitation rates in an active hydrothermal sulphide deposit on the Mid-Atlantic Ridge. Geology, 24:1147-1150.

Janecky, D.R., and Seyfried, W.E., 1984. Formation of massive sulfide deposits on oceanic ridge crests: incremental reaction models for mixing between hydrothermal solutions and seawater. Geochim. Cosmochim. Acta, 48:2723-2738.

Janecky, D.R., and Shanks, W.C., III, 1988. Computational modeling of chemical and sulfur isotopic reaction processes in seafloor hydrothermal systems: chimneys, massive sulfides, and subjacent alteration zones. Can. Mineral., 26:805-825.

Kushnir, J., 1982. The partitioning of seawater cations during the transformation of gypsum to anhydrite. Geochim. Cosmochim. Acta, 46:433-446.

Mills, R.A., Alt, J.C., and Clayton, T., 1996. Low-temperature fluid flow through sulfidic sediments from TAG: modification of fluid chemistry and alteration of mineral deposits. Geophys. Res. Lett., 23:3495-3498.

Mills, R.A., and Elderfield, H., 1995. Rare earth element geochemistry of hydrothermal deposits from the active TAG mound, $26^{\circ} \mathrm{N}$ Mid-Atlantic Ridge. Geochim. Cosmochim. Acta, 59:3511-3524.

Mitra, A., Elderfield, H., and Greaves, M.J., 1994. Rare earth element distribution in submarine hydrothermal fluids and plumes from the Mid-Atlantic Ridge. Mar. Chem., 47:217-236.

Schultz, A., Dickson, P., and Elderfield, H., 1996. Temporal variations in diffuse hydrothermal flow at TAG. Geophys. Res. Lett., 23:3471-3474.
Shannon, R.D., 1976. Revised effective ionic radii and systematic studies of interatomic distances in halides and chalcogenides. Acta Crystallogr., 32:751-767.

Shikazono, N., and Holland, H.D., 1983. The partitioning of strontium between anhydrite and aqueous solutions from $150^{\circ} \mathrm{C}$ to $250^{\circ} \mathrm{C}$. Econ. Geol. Monogr., 5:320-328.

Thompson, G., Humphris, S.E., Schroeder, B., Sulanowska, M., and Rona, P.A., 1988. Active vents and massive sulfides at $26^{\circ} \mathrm{N}$ (TAG) and $23^{\circ} \mathrm{N}$ (Snakepit) on the Mid-Atlantic Ridge. Can. Mineral., 26:697-711.

Tivey, M.K., 1995. Modeling chimney growth and associated fluid flow at seafloor hydrothermal vent sites. In Humphris, S.E., Zierenberg, R.A., Mullineaux, L.S., and Thomson, R.E. (Eds.), Seafloor Hydrothermal Systems: Physical, Chemical, Biological and Geological Interactions, Am. Geophys. Union, Geophys. Monogr., 91:158-177.

Tivey, M.K., Humphris, S.E., Thompson, G., Hannington, M.D., and Rona, P.A., 1995. Deducing patterns of fluid flow and mixing within the TAG active hydrothermal mound using mineralogical and geochemical data. $J$. Geophys. Res., 100:12,527-12,555.

Date of initial receipt: 3 June 1996

Date of acceptance: 10 June 1997

Ms 158SR-212

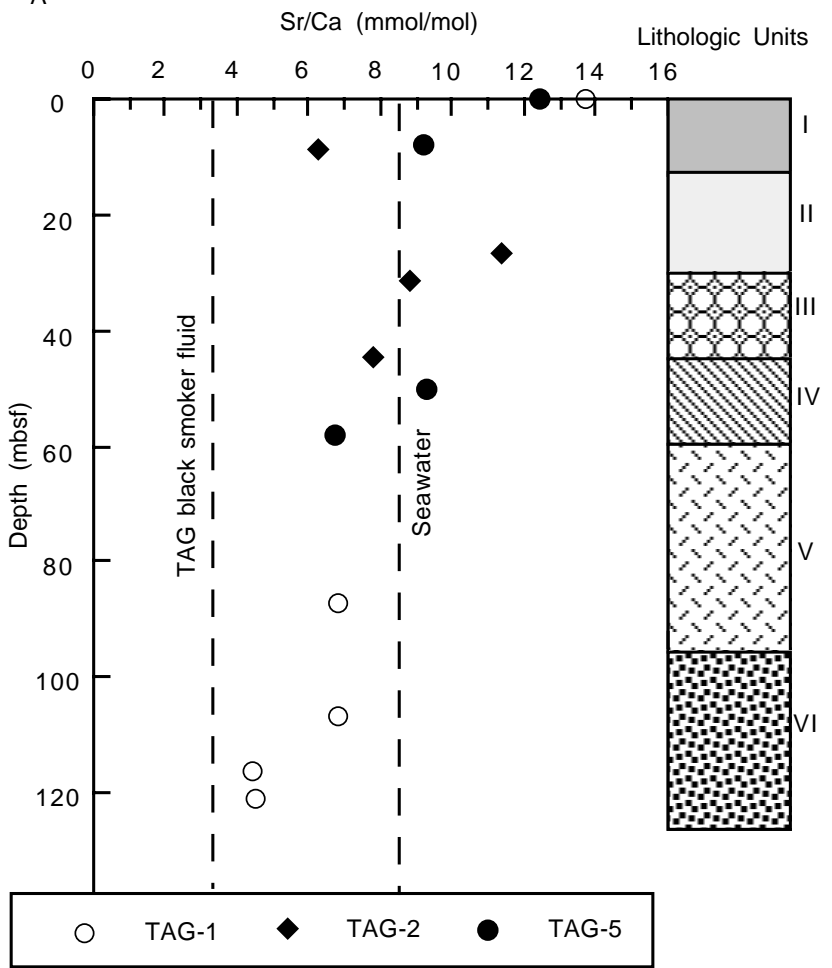

B

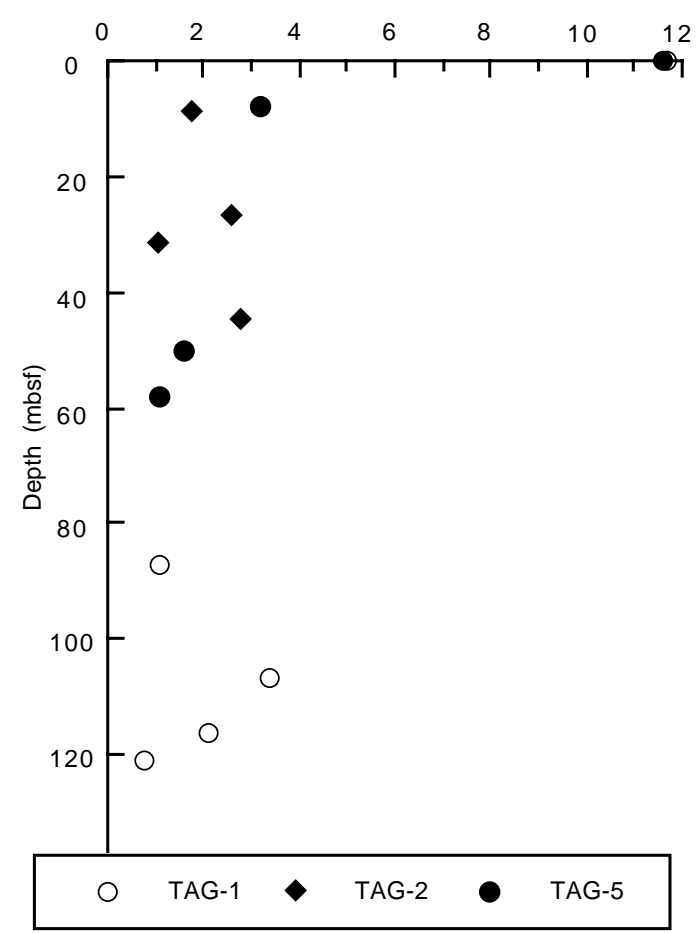

Figure 3. Downcore variation in (A) $\mathrm{Sr} / \mathrm{Ca} \mathrm{mmol} / \mathrm{mol}$ and (B) $\mathrm{Mg} / \mathrm{Ca} \mathrm{mmol} / \mathrm{mol}$, lithology as in Figure 1. TAG black smoker fluid and seawater values for Sr/ $\mathrm{Ca}$ are shown for comparison. Black smoker $\mathrm{Mg} / \mathrm{Ca}=0$, seawater $=4.9 \mathrm{mmol} / \mathrm{mol}$. 

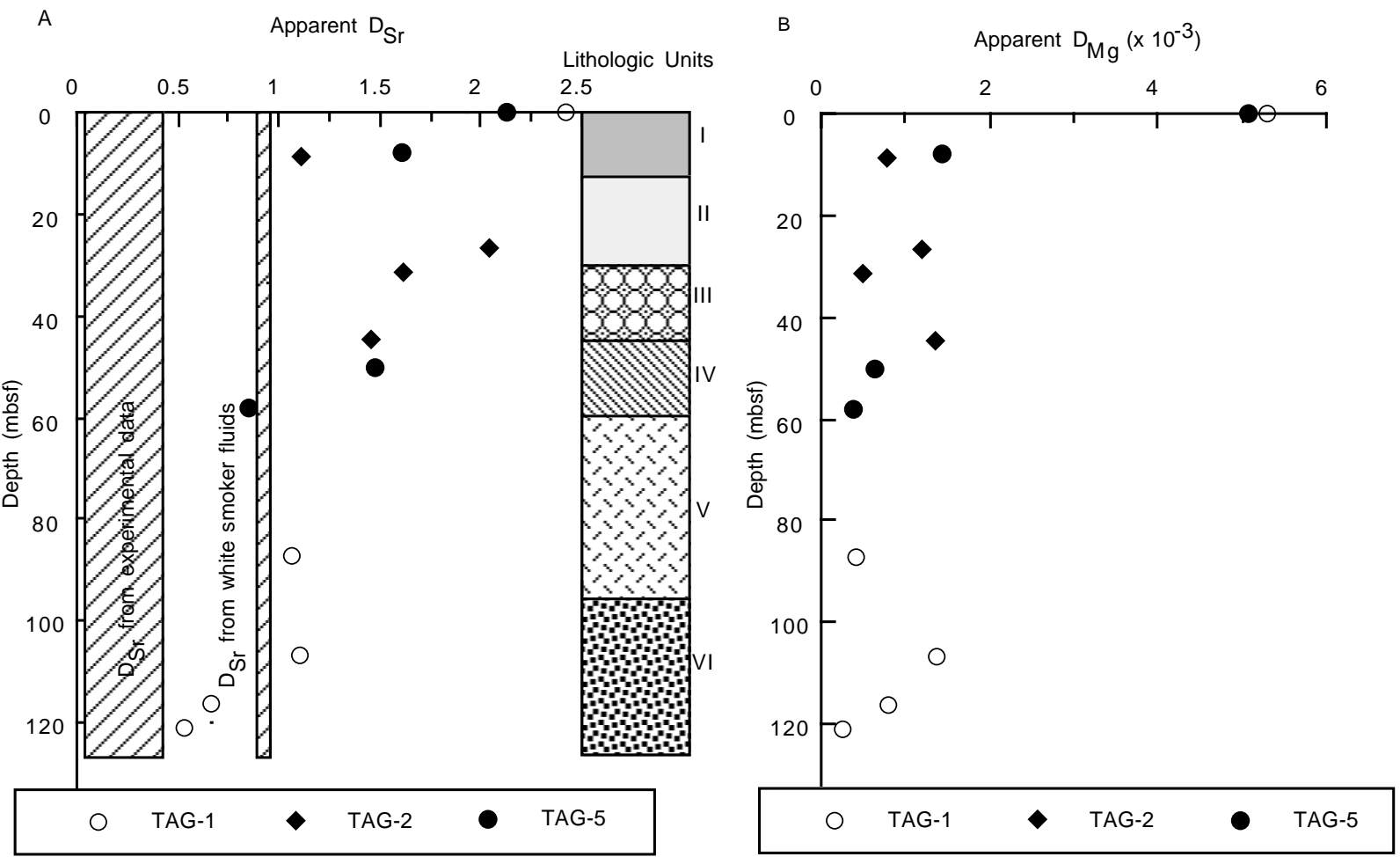

Figure 4. Downcore variation in $(\mathbf{A}) D_{\mathrm{Sr}}$ and $(\mathbf{B}) D_{\mathrm{Mg}}\left(\times 10^{-3}\right)$, lithology as in Figure 1. Experimental data from Shikazono and Holland (1983) and $D_{\mathrm{Sr}}$ values inferred from white smoker fluid data are shown for comparison.

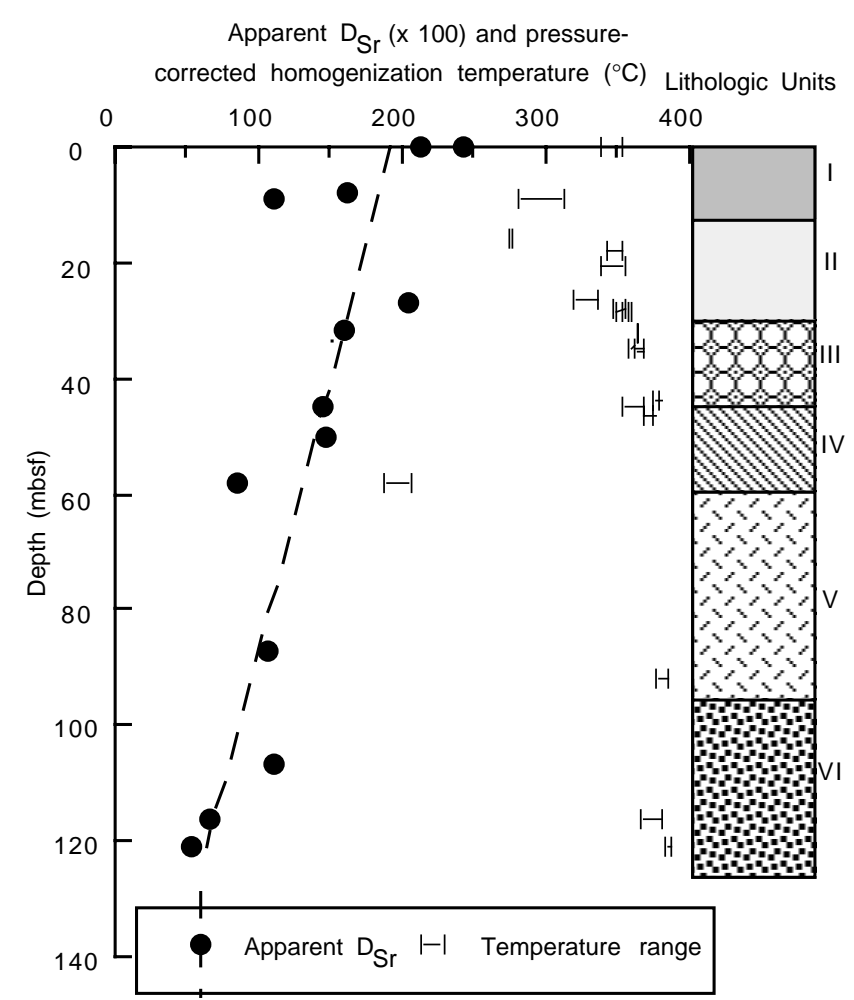

Figure 5. Downcore variation in all $D_{\mathrm{Sr}}$ data and pressure-corrected, fluidinclusion, homogenization temperature ranges observed in TAG anhydrite samples (data from Tivey et al., Chap. 14, this volume). The dashed line represents the least squares fit through the $D_{\mathrm{Sr}}$ data $(r=0.8)$; there is no significant correlation in the temperature data.
Table 3. Fluid data for TAG fluids and seawater.

\begin{tabular}{lccc}
\hline & Seawater & $\begin{array}{c}\text { Black smoker } \\
\text { fluid }\end{array}$ & $\begin{array}{c}\text { White smoker } \\
\text { fluid }\end{array}$ \\
\hline Temperature $\left({ }^{\circ} \mathrm{C}\right)$ & 2.7 & 364 & $273-301$ \\
$\mathrm{Ca}(\mathrm{mM})$ & 10.3 & 30.8 & 27.0 \\
$\mathrm{Mg}(\mathrm{mM})$ & 53 & 0 & 0 \\
$\mathrm{Sr}(\mu \mathrm{M})$ & 88 & 103 & 91 \\
$\mathrm{Sr} / \mathrm{Ca}\left(\times 10^{-3}\right)$ & 8.54 & 3.34 & 2.62 \\
$\mathrm{Mg} / \mathrm{Ca}$ & 5.15 & 0 & 0 \\
${ }^{87} \mathrm{Sr} /{ }^{86} \mathrm{Sr}$ & 0.70916 & 0.70319 & 0.70319 \\
\hline
\end{tabular}

Note: Data are from Campbell et al. (1988), Edmond et al. (1995), and Elderfield et al. (1993). 


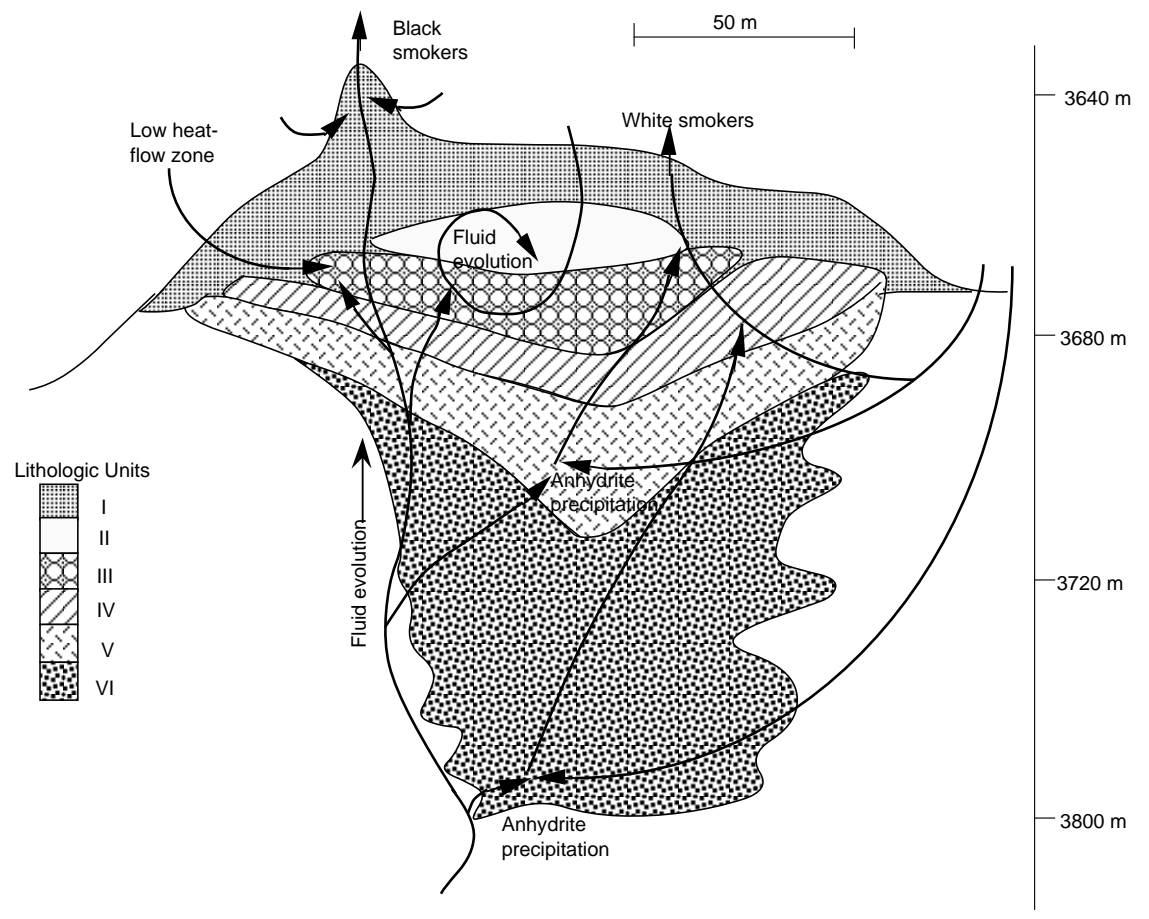

Figure 6. Schematic circulation of fluid within the TAG mound inferred from this study, lithology as for Figure 1. Arrows demonstrate seawater penetration into the mound and fluid pathways inferred from the present study. 